\title{
Notes
}

\section{Post-Modern Art and the Death of Obscenity Law}

\begin{abstract}
Amy M. Adler
In 1973, in Miller v. California, ${ }^{1}$ the Supreme Court wrested from the "tortured history"2 of its obscenity doctrine the modern constitutional definition of "obscenity." Miller set forth a new test to distinguish sexually explicit art $^{3}$ from obscenity, protecting such art only if it demonstrates "serious . . . artistic . . . value." Yet Miller was drafted at a radical turning point in the history of art, and the new art that has arisen since Miller has rendered standards such as "serious artistic value" obsolete. This new art-Post-Modern $\operatorname{art}^{5}$-rebels against the demand that a work of art be "serious, or that it have any traditional "value" at all. Miller, then, evaluates contemporary art by the very standard which that art seeks to defy. ${ }^{6}$
\end{abstract}

1. 413 U.S. 15 (1973).

2. Id. at 20 .

3. This Note will not define the term "art"; rather, it will argue that we cannot define the term because contemporary art, by its very nature, will defy any definition that we assign to it. The Note will use the term "art" to describe works that critics, scholars, galleries, museums, and "artists" generally discuss as "art." This is not to say that critical acceptance by that community is definitive as to what "art" means. From the author's point of view, critical acceptance is sufficient reason to call a work "art," but not a necessary one; works currently not accepted by the "art" world nonetheless may be "art."

4. Meller, 413 U.S. at 24.

5. For an explanation of Post-Modern art, see infra notes 28-70 and accompanying text.

6. An understanding of the danger that Miller poses for contemporary art has become particularly pressing since the recent "Mapplethorpe" controversy over government funding of sexually explicit art, see iufia notes 79-81 and accompanying text, not only because that debate evidences an increasingly hostile and therefore dangerous climate for sexually explicit art, but because the artistic value test in Miller has now been incorporated into the new standard for Federal funding of art. Art which 
Section I of the Note explores the Miller test, its critics, and the Court's recent reexamination of the test in Pope v. Illinois. ${ }^{2}$ Section II articulates three major themes of Post-Modern art and traces their implications for the Miller standard. After demonstrating the inadequacy of the Miller test for protecting contemporary art, this Note, in Section III, examines other standards that might offer more protection for art than Miller does. Nonetheless, even these standards fail to provide sufficient protection for artistic expression, for, as the Note concludes, the two basic goals of obscenity law-protecting art while controlling obscenity-lie in a state of irreconcilable conflict due to the nature of contemporary art. $^{8}$

\section{The Miller Test and Its Critics}

In 1957, when the Supreme Court in Roth v. United States ${ }^{9}$ explicitly proclaimed that a sector of speech defined as "obscenity" fell outside of the constitutional protection of the First Amendment, ${ }^{10}$ it necessarily made the definition of "obscenity" a matter of constitutional law. ${ }^{11}$ The realm of the "obscene" became a no-man's land surrounding the fortress of the First Amendment: only speech that could defy the definition of obscenity and gain access to the First Amendment's safe walls would merit protection. Yet the determination of these boundaries proved far from clear-cut for the Supreme Court; it had set out to define what in fact "may be indefinable." 12 The "intractable obscenity problem"13 plagued the Court in the years that followed Roth. It was not until the 1966 case of Memoirs v. Massachusetts ${ }^{14}$ that the Court attempted to clarify its definition, and even then it failed to produce a majority opinion.

Finally, in 1973, in Miller v. California, the Court articulated a new

fails the Miller "serious value" test no longer will have access to Federal grants. See Pub. L. No. 101$121, \S 304,103$ Stat. 741, 741-42 (1989) (banning Federal grants for "obscene" art which lacks serious value).

7. 481 U.S. 497 (1987).

8. This Note does not purport to argue which of these two conflicting goals-the prohibition of obscenity or the full protection of art-is more important to society. It argues only that we choose one goal at the expense of the other; we must, therefore, evaluate what we lose by choosing either alternative. Philosophers of aesthetics too numerous to mention in the context of this Note have discussed the inherent and societal values of art. For a legal theory of the importance of art to society, see Meiklejohn, The First Amendment Is an Absolute, 1961 SuP. CT. REv. 245, 262 (literature and arts can inform political process by imparting sensitivity to human values). For legal arguments that other concerns should take precedence over the protection of art, see Bork, Neutral Principles and Some First Amendment Problems, 47 IND. L.J. 1, 20-29 (1971) (art merits no First Amendment protection), Paris Adult Theatre I v. Slaton, 413 U.S. 49, 57-63 (1973) (explaining importance to communities of prohibiting obscenity), and C. MACKinNon, Feminism UnModified (1987) (pornography institutionalizes second-class, victimized status for women in society).

9. 354 U.S. 476 (1957).

10. Id. at $484-85$.

11. Sep H. Kalven, A Worthy Tradition 37 (1988).

12. Jacobellis v. Ohio, 378 U.S. 184, 197 (1964) (Stewart, J., concurring).

13. Interstate Circuit, Inc. v. City of Dallas, 390 U.S. 676, 704 (1968) (Harlan, J., concurring and dissenting).

14. 383 U.S. 413 (1966). 
definition of "obscenity" that reigns supreme to this day. For the first time in sixteen years, a majority of justices had managed to agree on a definition of a term that had "produced a variety of views among the members of the Court unmatched in any other course of constitutional adjudication." 18 Yet in the shadow of the Court's relative triumph was the disenchantment of a solid four-member dissenting minority (as well as a community of legal scholars) who had abandoned all faith in Miller's project and had grown to doubt the possibility of a constitutionally acceptable distinction between obscenity and protected speéch.

Miller v. California set forth a three-part test for determining whether a given work should be labelled "obscene":

(a) whether "the average person, applying contemporary community standards" would find that the work, taken as a whole, appeals to the prurient interest;

(b) whether the work depicts or describes, in a patently offensive way, sexual conduct specifically defined by the applicable state law; and

(c) whether the work, taken as a whole, lacks serious literary, artistic, political, or scientific value. ${ }^{16}$

Since it was drafted in 1973, the Court has continued to follow Miller despite persistent criticism of the test. ${ }^{17}$ Critics have pointed to the Court's failure to provide a workable definition of obscenity ${ }^{18}$ and have argued that because the standard is vague and unpredictable, it will chill speech that ought to be protected. ${ }^{19}$

Certain critics have focused specifically on the third prong of the test, in part because it represents a significant departure from the Court's prior obscenity holdings. Whereas both Roth and Memoirs had held that a work

15. Interstate Circuit, 390 U.S. at 704-05, 705 n.1 (Harlan, J, concurring and dissenting).

16. Miller v. California, 413 U.S. 15, 24 (1973) (citations omitted). Miller involved an obscenity prosecution against a defendant who had mailed brochures advertising sexually explicit books.

17. E.g., Paris Adult Theatre I v. Slaton, 413 U.S. 49, 73 (1973) (Brennan, J., dissenting) (Miller standard is vague, fails to provide adequate notice, will chill protected speech, and will mire courts in case-by-case litigation); Note, Community Standards, Class Actions, and Obscenity Under Miller v. California, 88 Harv. L. REv. 1838 (1975) (Miller's ambiguity will chill protected speech); The Supreme Court, 1972 Tern, 87 HaRv. L. Rev. 57, 160-75 (1973) (same).

18. This problem did not originate with Miller; it has been a constant point of disagreement for the Court ever since Roth. See H. Kalven, supra note 11, at 33-53. Summing up the Court's frustrating task, Justice Stewart wrote that although it may be impossible to define hard-core pornography, "I know it when I see it." Jacobellis v. Ohio, 378 U.S. 184, 197 (1964) (Stewart, J., concurring).

Miller did provide that only "hard-core" sexual imagery should be banned under the test, 413 U.S. at 27, but failed to give a definition for the term. See, e.g., F. Schauer, The Law of Obscenity 109-13 (1975) (noting that meaning of hard-core pornography has "been elusive for many years. . . . [I]t is more of a conclusion than a test").

19. See supra note 17. For a discussion of the chilling effect of obscenity regulation in general, see Ginzburg v. United States, 383 U.S. 463, 480-81 (1966) (Black, J., dissenting); F. SCHAUER, FrEE SPEECH: A PhILOSOPHICAL ENQUIRY 178-79 (1982) (noting obscenity regulation's history of plain errors in banning what we now consider great works of art). 
had to be "utterly without redeeming social value"20 before it could be banished to the constitutional no-man's land of "obscenity," Miller rejected this expansive test in favor of a standard that protected less art and was easier for the prosecution to meet. ${ }^{21} \mathrm{~A}$ work of art now needed to possess "serious value" to gain protection. As Justice Brennan noted in his dissent to Miller's companion case, Paris Adult Theatre I v. Slaton:

The Court's approach necessarily assumes that some works will be deemed obscene-even though they clearly have some social value-because the State was able to prove that the value, measured by some unspecified standard, was not sufficiently "serious" to warrant constitutional protection. That result is . . an invitation to widespread suppression of sexually oriented speech. ${ }^{22}$

In the 1987 case of Pope v. Illinois, ${ }^{23}$ the Court, added a new edge to Miller's third prong that only exacerbated the deep problems that plague the test. ${ }^{24}$ Since Pope, the "proper inquiry is . . . whether a reasonable person would find [serious] value in the material."25 But as Justice Scalia noted wearily: "Since ratiocination has little to do with esthetics, the fabled 'reasonable man' is of little help in the inquiry. . . . [T]oday's opinions . . . display the need for reexamination of Miller."28

The Pope Court, like the Miller Court, assumed that serious artistic value provided a workable standard that could distinguish sexually explicit art from obscenity. In the following section, this Note argues that this basic assumption is wrong, that serious value is no longer a coherent standard in the face of recent developments in art.

\section{POST-MOdernism ANd ITS Implications FOR MILLER}

Chief Justice Burger devised the Miller test for "serious artistic value" at precisely the time that Modernism in art was in its death throes. One year earlier, the art critic Leo Steinberg had been perhaps the first to apply the name "Post-Modernism"27 to the revolutionary artistic movement that was budding just as Miller was decided. That the Court drafted

20. Memoirs v. Massachusetts, 383 U.S. 413, 419 (1966) (emphasis in original).

21. 413 U.S. at 22 (interpreting Roth's third prong as creating "a burden virtually impossible to discharge" for prosecution).

22. 413 U.S. 49, 97 (1973) (Brennan, J., dissenting); see also H. KALVEN, supra note 11, at 50 (new test no longer protects art that previous obscenity holdings would have protected).

23. 481 U.S. 497 (1987). Pope was an obscenity prosecution against two attendants at "adult" bookstores in Illinois. Id. at 499 .

24. The Pope Court confirmed what had already been implicit in Miller: its third prong requires the application of an objective rather than a community standard. Id. at 500-01. In Smith v. United States, 431 U.S. 291, 301 (1977), the Court had noted that Miller implicitly rejected a community standards approach to interpretation of the third prong of the test.

25. Pope, 481 U.S. at 500-01.

26. Id. at 504-05 (Scalia, J., concurring).

27. See L. Steinberg, Other Criteria, in Other Criteria: Confrontations with TwentiETH-CENTURY ART 91 (1972). 
Miller at this turning point in art has dramatic implications, for the metamorphosis into Post-Modernism that occurred in the 1960's and early 1970's has led not to another style in art, but to an entirely transformed conception of what "art" means. ${ }^{28}$

Attempts to define Post-Modernism in the arts often have failed, perhaps because Post-Modernism represents not a single, clear movement, but a pluralist and many-faceted rebellion against the dictates of Modernism. ${ }^{2 \theta}$ To begin to understand recent art, therefore, we must first consider Modernism. ${ }^{30}$ It was a movement that began in the 1860's with the painter Manet and self-destructed-or some would say reached its apogee-in the Minimalist movement of the late 1960 's. ${ }^{31}$ Yet it was a particular breed of Modernism-"late Modernism"-that became the focus of Post-Modern art. Critics and artists of the Post-Modern era universally seem to equate the Modernism against which they rebel with the formalist doctrine of Clement Greenberg, the leading critic of late Modernism, whose critical vision of art triumphed in the 1950's. ${ }^{32}$

Modernism as articulated by Greenberg and his peers was a purist movement. ${ }^{33}$ Greenberg believed that art could "maintain [its] past standards of excellence"34 by using the "characteristic methods of a discipline to criticize the discipline itself-not in order to subvert it, but to entrench it more firmly in its area of competence."35 Late Modernism distinguished between good art and bad $\operatorname{art}^{36}$ by demanding that good art be pure, selfcritical, original, sincere, ${ }^{37}$ and serious.

Post-Modernism rebelled against the stifling and idealistic confines of

28. Wallis, What's Wrong with This Picture?, in ART AFTER MODERnism: Rethinking RePRESEntation (B. Wallis ed. 1984). But see Habermas, Modernity: An Incomplete Project, in The ANTI-AEsThÉtIC 3 (H. Foster ed. 1983) (current period represents continuation of Modernism).

29. Jameson, Postmodernism and Consumer Saciety, in The ANTI-AfstHetic, supra note 28, at 112.

30. See generally Modern Art and Modernism: A Critical Anthology (F. Frascina \& C. Harrison eds. 1982).

31. For an account of Minimalism's relation to Modernism, see H. Foster, Against Pluralism, in Recodings: ART, Spectacle, Cultural Polmics 13 (1985).

32. See, e.g., Wallis, supra note 28, at xii; P. Halley, Against Post-Modernism: Reconsidering Orlega, in Coll.ected Essays 1981-1987, at 27 (1988). Michael Fried perhaps rivals Greenberg as an influential critic of late Modernism. See, e.g., Fried, Art and Objecthood, ARTforum, June 1967, at 12 .

33. See, e.g., Greenberg, Modernist Painting, in MOdern ART And Modernism, supra note 30 , at 6 ("art . . . in its 'purity' [would] find the guarantee of its standards of quality").

34. Id. at 10 .

35. Id. at 5 .

36. Clement Greenberg wrote in 1955, "There is good and bad in [contemporary painting], and ... the difference ... owes its realization to a severer discipline . . . G Greenberg, "AmericanType" Painting, in Modern ART AND MODERnisM, supra note 30, at 94; see also C. GREENBERG, Az'ant-Garde and Kitsch, in ART and Culture: CrItrcal. Essays 3 (1961) (finding value in high art but not in kitsch).

37. See, e.g., Hughes, The Rise of Andy Warhol, in ART AFter Modernism: Rethinking REPRESENTATION, supra note 28 , at 49 (noting belief "dear to modernism, that . . . art flowed from the unconscious," thus presumably representing artist's sincere emotions). This notion was exemplified in Modernist Abstract Expressionism. 
late Modernism. It attacked the Modernist distinctions between good art and bad, between high art and popular culture, between the sanctity of the art context and real life. Post-Modernism not only rejected the Modernist demand that art be "serious," it rejected the idea that art must have any traditional "value" at all. It mocked notions of originality and authenticity; it replaced sincerity with cynicism.

The wording of Miller clearly reflects the Modernist era in which it was drafted. As an art critic wrote of Modernism, "the highest accolade that could be paid to any artist was this: 'serious." "38 It is as if the word "serious" were a codeword for Modernist values: critics consistently equate it with the Modernist stance. ${ }^{39}$ In fact, the very foundation of Miller, the belief that some art is just not good enough or serious enough to be worthy of protection, mirrors the Modernist notion that distinctions could be drawn between good art and bad, and that the value of art was objectively verifiable. ${ }^{40}$ Thus Miller has etched in stone a theory of art that was itself a product of only a transitory phase in art history-the period of late Modernism.

Miller, however, has not suddenly become a dangerous standard only now that Post-Modern art has become the dominant mood of the era. Coexisting with the Modernist movement itself were ideas which strained the measure of "serious artistic value." In order to realize his pure ideology, Greenberg, the leading late Modernist critic, had been forced to ignore an important twentieth-century counter-tradition to Modernism that preceded Post-Modernism: Dadaism (exemplified in the work of Marcel Duchamp), Surrealism, and later, Pop. ${ }^{41}$ It was this counter-tradition that ultimately triumphed. Its elements of non-seriousness-of impurity and irreverence-were like weeds that had taken root and ultimately strangled the neatly planted rows of Greenberg's Modernist garden, despite all his diligent tending. Much of Post-Modern art derives from seeds sown by Marcel Duchamp in the 1920's. ${ }^{42}$ Although this Note focuses on the inadequacy of Miller in the face of contemporary art, it is crucial to note that Miller was inadequately narrow even before the advent of PostModernism. Like the late Modernist tradition from which the Miller Court's logic sprung, the Miller standard failed to account for an entire counter-tradition to Modernist art.

The Modernist standards for evaluating art which are embodied in

38. Davis, Post-Performancism, ARTFORUM, Oct. 1981, at 31, 39.

39. See, e.g., Crow, These Collectors, They Talk About Baudrillard Now, in Discussions IN Contemporary Culture 1 (H. Foster ed. 1987) (noting "humorless seriousness of high modernism").

40. See, e.g., Wallis, supra note 28 , at xii.

41. See, e.g., Buchloch, Periodizing Critics, in Discussions in Contemporary Culture, supra note 39 , at 65 .

42. See, e.g., Carlin, Culture Vultures: Artistic Appropriation and Intellectual Property Lau, 13 Colum. J.L. \& ARTS, 103, 104-05 (1988). 
Miller have been destroyed and none have taken their place; ${ }^{43}$ perhaps the only standard left is to defy all standards. The Miller test has become as obsolete as the Modernist tradition in which it was grounded: Miller evaluates artistic expression by the very criteria that Post-Modern art seeks to defy.

\section{A. Themes of Post-Modernism and Their Implications for Miller}

What did the Miller Court mean by "serious artistic value"?44 There are at least three plausible interpretations: (1) the artwork makes an important and original rather than a marginal and derivative contribution to art; $^{48}$ (2) the artwork is "serious" in that it reflects the sanctity and solemnity of high $\operatorname{art}^{48}$ (3) the artist was serious and sincere in his attempt to make art (rather than obscenity), no matter how successful his ultimate achievement. ${ }^{47}$ This subsection tests each of these three interpretations of serious value against examples of Post-Modern art. ${ }^{48}$ Ultimately, each will prove inadequate when thus applied because each rests on assumptions which Post-Modernism rejects.

43. Sic L. Stringerg, supra note 27, at 91 (Post-Modernism has left "old stand-by criteria" for evaluating art "to rule an eroding plain"). Of course, it is still true in the Post-Modern era that individual critics and schools of criticism have certain standards by which they evaluate art. I simply mean that there is no longer a universally agreed upon standard, as there was in the days that Clement Greenberg's ideology dominated late Modernism. This reflects the Post-Modern tendency to undermine and reject the Modernist assumption (based on Kantian notions of aesthetics) that there can be universal judgments of taste. See Owens, The Discourse of Others: Feminists and Postmodernism, in ThE ANTr-AEsTHETIC, supra note 28 , at 58.

44. Critics of Mrllor have pointed to the Court's failure to provide examples of what would constitute serious value. St', e.g., Note, Community Standards, Class Actions, and Obscenity Under Miller v. California, 88 HaRv. L. REv. 1838 (1975); Note, Taking Serious Value Seriously: Obscenity, Pope v. Illinois and an Objotiz' Standard, 41 U. Miami L. Rev. 855 (1987).

45. Stt, e.g., Andrews v. State, 652 S.W.2d 370, 389 (Tex. Crim. App. 1983) (en banc) (equating serious value with important value); H. KaLven, supra note 11, at 50 .

46 Sit, $k g$, F. SCHAUER, supra note 18, at 145 ("While literature need not necessarily be serious, or dry, entertainment value or humor cannot be equated with literary value."); see also People ex wl. Hicks " "Sarong Gals," 27 Cal. App. 3d 46, 103 Cal. Rptr. 414, 417 (1972) (entertainment value does not equal literary value); $f$. Crow, supra note 39, at 1 (noting "[the] humorless seriousness of high modernism"); Greenberg, supra note 33, at 5-10 (noting Modernism's rejection of popular culture in favor of standards of purity, quality, and discipline).

47. The Supreme Court first suggested this interpretation in a pre-Miller ruling, Kois v. Wisconsin, 408 U.S. 229, 231 (1972). The poem in question bore "some of the earmarks of an attempt at serious art." Ser' also United Artists Corp. v. Gladwell, 373 F. Supp. 247, 249 (N.D. Ohio 1974) (") [W]hether the artist succeeds or fails . . . is no test of the seriousness of the work or its purpose."); State v. Walden Book Co. 386 So. 2d 342, 345 (La. 1980) (if intent is to convey artistic idea, then intunt is serious); Main, The Neglected Prong of the Miller Test for Obscenity: Serious Literary, Arthuc, Pulthral, or Sczentyfic Value, 11 S. ILL. U.L.J. 1159 (1987) (courts should examine sincerity of artist's intent rather than artwork itself to determine serious value); Schauer, Speech and "Spech"-Obscemty and "Obscenity": An Exercise in the Interpretation of Constitutional Language, 67 GEo. L.J. 899, 929 (1979) (serious "must be defined in terms of intent alone").

48. I do not mean to suggest that the three themes of Post-Modernism discussed below represent a thorough account of the major principles of this anarchic movement. They are simply the aspects of Post-Modernism that are most relevant for an assessment of Miller, but hardly an exhaustive characterization of Post-Miodernism. 


\section{The End of Originality and the Avant Garde}

"No new tale to tell" - Love and Rockets"

One of the major hallmarks of Post-Modernism is its rejection of the Modernist quest to be new, original, and avant-garde. ${ }^{50}$ Post-Modern art is aggressively derivative. As the art critic Brian Wallis wrote, "Today no action, no feeling, no thought we own has not been performed by a thousand movies, commercials, television sitcoms, or magazine articles. Our society, supersaturated with information and images, not only has no need for individuality, it no longer owns such a concept."

Consider the appropriation artist Sherrie Levine. In the early 1980's Levine's art consisted of taking famous art photographs and simply rephotographing them as a means of deconstructing the Modernist belief in originality. ${ }^{\mathbf{2}}$ Or take as an example the painter David Salle, who layers and juxtaposes images that he appropriates from art history as well as from popular culture-pornography, fashion illustrations, and cartoons-in order to show the impossibility of originality in the PostModern era. By joining unconnected images, Salle invites the viewer to search for a narrative in his paintings, yet none exists. ${ }^{53}$ Rather, Salle seeks to show the muteness and futility of his images in the wake of Modernism and its emphasis on originality. A critic has called Salle's paintings "dead, inert representations of the impossibility of passion in a culture that has institutionalized self-expression." about "all the paintings I won't make or can't make. . . ." 55

The Miller test presupposes a theory of art which Salle and Levine reject. As Harry Kalven wrote of Miller: "It is of course unlikely that Ulysses will again be banned, but there is a danger under the new test that a second-rate Ulysses which the Court does not regard as sufficiently 'serious' will be." ${ }^{\text {g6 }}$ The problem is that in Post-Modern art, the next Ulysses is likely to be a work that is precisely about its own "secondrateness." This is the thrust of Levine's and Salle's art: all they have left to them is to recycle images, whether from high art or from low culture, because it has all been done before. Modernism, which equated a first-

49. Love and Rockets, No New Tale to Tell (Big Time Records 1987).

50. Sep C. Robins, The Pluralist ERa: American ART 1968-1981, at 1-2 (1984).

51. Wallis, supra note 28, at xvii-xviii; see also Baudrillard, The Precession of Simulacra, in ART AFTER MODERNISM: Rethinking REPRESEnTATION, supra note 28, at 253, 254 (our culture now substitutes "signs of the real for the real itself").

52. Krauss, The Originality of the Az'ant-Garde: A Postmodernist Repetition, OcroBer, Fall 1981 , at $47,64-66$.

53. See Owens, Back to the Studio, ArT AM., Jan. 1982, at 99, 103.

54. Lawson, Last Exit: Painting, ARTForum, Oct. 1981, at 40, 42.

55. Owens, supra note 53, at 103 (quoting Images That Understand Us: A Contersation With David Salle and Jaimes Welling, LAICA J., June-July 1980, at 44).

56. H. KALvEN, supra note 11 , at 50 (emphasis in original). 
rate or serious painting with originality, ${ }^{57}$ is over. By celebrating their derivativeness, artists like these attack one of the basic standards that established the value of Modernist art. Thus if we interpret "serious value" to mean that a work of art makes a significant rather than a marginal contribution to art, this standard would fail to protect many Post-Modern artists. If a Levine photograph of another artist's photograph makes an important contribution to art, it is only because her work is on some level about her inability to make an important contribution to art.

\section{Defiance of Serious Artistic Value}

[T] he 80's has been the decade in which art that denies the value of art has become the most valuable art around. ${ }^{\mathrm{s}}$

A second possible meaning for "serious value" may be that the work of art reflects the sanctity and solemnity of high art, as opposed to mass culture. But one of the essential tenets of Modernism that PostModernism attacks is the canonical distinction between high art and popular culture. ${ }^{58}$ Thus a critic wrote in 1975 that Andy Warhol had "liquidated the century-old [Modernist] tension between the serious artist and the majority culture." ${ }^{\prime 00}$ Post-Modern artists reject the solemnity associated with late Modernism by incorporating images of kitsch, humor, entertainment, and media into their work. ${ }^{61}$ For example, the artist Julie Wachtel traces cartoon figures from cheap greeting cards directly onto canvas. Her paintings reject "not just the idea of originality but the idea of Quality." ${ }^{22}$ Is "serious value" an appropriate standard by which to judge these works? Wachtel mocks notions of value. Her images are whimsical and lowly; her message is that even a cheap card is art.

Artist Jeff Koons' work looks like tacky lawn sculpture. For one of his most recent designs, Koons hired highly skilled Italian artisans to create a porcelain porn star in the arms of the Pink Panther. As an art critic wrote of Koons (who has been centrally featured in prestigious recent Whitney Museum Biennials): "While Pop Artists could make art that looked like trash and slyly celebrated high art, Mr. Koons makes art that looks like trash and trashes high art." ${ }^{13}$ It is as if Koons' central aim is to challenge the distinction between trash and valuable art that forms the very foundation of the Miller test.

57. See, e.g., Foster, Re: Post, in ARt After MOdernism: Rethinking Representation, supra note 28 , at $189,191$.

58. Frank, Art's Off-the-IWall Critic, N.Y. Times, Nov. 19, 1989, §6 (Magazine), at 78.

59. See C. GReEnBERG, supra note 36 , at 3.

60. Hughes, supra note 37, at 54 (quoting critic Harold Rosenberg) (emphasis added).

61. See, e.g., Davis, supra note 38, at 39; Klein, The Audience Culture, in Theories of CoNTEMPORARY ART 265 (R. Hertz ed. 1985).

62. Levin, Stason's Greptings?, Village Voice, Dec. 21, 1985, at 81.

63. Brenson, Shifting Image and Scale, N.Y. Times, Dec. 2, 1988, at C22, col. 5. 
In fact, Post-Modern art does not merely reject the serious value standard; it defies any standard used to judge it. For example, the late 1970's movement called "Bad Painting" rebelled against Modernist distinctions between good art and bad art by employing tasteless images, inept drawing, poor craftsmanship, and unschooled color. ${ }^{64}$ This kind of art mocks anyone who attempts to determine its "value." Its aim is to ridicule the notion that we can distinguish between works of "serious value" and bad art. In fact, it challenges the possibility of any critical standard.

\section{The Death of the Artist: Sincerity and Intent}

Finally, "serious value" might be read as an inquiry into the artist's intentions rather than a judgment about the work's value. The question becomes "did the artist sincerely intend to create art?" In those rare instances when serious value is discussed at all by courts and critics, this is the favored interpretation of the term. ${ }^{65}$ But this interpretation also proves troublesome when applied to recent art because Post-Modernism regards notions of intentionality and sincerity as naive Modernist constructs. ${ }^{68}$ Rather than allowing the viewer to rely on these former guideposts, PostModern art often pressures the viewer to consider the absence of the artist, and the presence of multiple possibilities of interpretation which arise when the artist's intent becomes unknowable. ${ }^{67}$

For example, David Salle's strategy of painting in several different styles within the same painting raises numerous interpretive possibilities and makes us question whether or not the painter is sincere, throwing into doubt the Modernist assumption that an artist's style and gesture are his signature, the guarantor of his sincerity and authenticity. ${ }^{68}$ Salle presents sincerity as just another pose. Is Wachtel's tracing of a cheap greeting card really a sincere effort to make art, or a mockery of art? As a painter in the Bad Painting movement said, "There is only bad art because there is no such thing as art." ${ }^{\text {"69 }}$ Can we say that his paintings are therefore

64. Plagens, The Aciademy of the Bad, in Theories of ConTEMPORARY ART, supra note 61, at 83; Tucker, "Bad" Painting, in "BAD" Painting (1978) (catalogue of show at New Museum of Contemporary Art) (Bad Painting avoids "conventions of high art" and is "shocking and funny").

65. See supra note 47.

66. The Post-Modern critique of sincerity stems in part from the larger movement in Poststructuralist criticism to expose the impassibility of discovering an author's intentions. For critical rejections of the claim that the meaning of a text resides in the author's intent, see Barthes, The Death of the Author, in IMAGE-Music-Text 142 (S. Heath trans. 1977); Foucault, IVhat Is An Author?, in Textual Strategies 141 (J. Harari ed. 1979). See also J. Derrida, Of Grammatology (1968). Freud was obviously a central influence on these theories. At the risk of oversimplifying, Freudian notions of the unconscious lead inevitably to the idea that even an artist himself may be unaware of his "true" intentions.

67. See, e.g., Brenson, When Self-Consciousness Became King, N.Y. Times, Feb. 18, 1990, § 2, at H39, col. 1.

68. See, e.g., Krauss, supra note 52.

69. Tucker, supra note 64; see also Jameson, supra note 29, at 116 (one "essential message" of Post-Modernism is "the necessary failure of art"). 
earnest attempts to create art? Terms such as "sincere" and "earnest" are as inappropriate to describe contemporary art as "serious" is. How can we use such standards to evaluate the deeply cynical and jaded art that has arisen in the Post-Modern era? ?70 $^{70}$

\section{B. The Intersection of Art and Obscenity}

The most pressing challenge to the Miller test comes from a sector of Post-Modern artists who not only defy standards like serious value, but also attack the most basic premise of Miller: that art can be distinguished from obscenity. Some of the artists described in the following section of this Note are extremely-and deliberately-shocking and offensive. It may be hard to understand the value that critics find in this kind of work. Yet it is precisely because these works are so hard for many people to see as "art" that they are of pressing importance for the legal community to consider. The art I will describe below illustrates the chasm that has formed between contemporary artistic practice and legal theories of art-theories like Miller, which purport to distinguish art from obscenity by relying on such standards as "serious artistic value."

An important and established artist to consider is Karen Finley, whose performance art has been called "obscenity in its purest form." " She is indeed a shocking performer. She smears food into her genitals and has even defecated onstage; in her performances she graphically describes violent and bizarre sex acts with priests, children, relatives, and the handicapped. ${ }^{72}$

Annie Sprinkle is another performance artist whose work challenges the distinction between art and obscenity. Sprinkle works in the pornography industry, appearing in magazines and X-rated movies; yet she also performs in art settings, and elements from the two worlds commingle in her work. For example, she appeared in 1988 at the Kitchen Center for the Performing Arts"3 "Carnival of Sleaze" Festival. There she gave a performance that included elements from another performance she had given

70. In spite of all of these considerations, surely there exists contemporary art that is "original," or solemn, or deadly sincere. Nowhere is this more evident than in the highly political art that has arisen in response to AIDS. See, e.g., AIDS: Cultural ANAlysis/ Cultural Activism (D. Crimp ed. 1989). Nonetheless, the critique of sincerity and intentionality remains central to a great deal of Post-Modern art; to judge art based on an artist's constructive intent would be to impose on it a standard that contemporary art as a movement resoundingly rejects. One might argue further, however, that even art which criticizes notions of sincerity may nonetheless be sincere. "Aren't these artists serious about deriding seriousness?" the argument might go. Yet how could a court or a jury distinguish an artist who is "serious" about rejecting seriousness from one who does so with irreverence or cynicism about his very project? In the end, this question returns us to the naive question with which we began and which Post-Modern art rejects as unanswerable: what did the artist intend?

71. Carr, Karen Finley, ARtrorum, Nov. 1988, at 148.

72. See Carr, Unspenkable Practices, Unnatural Ack: The Taboo Art of Karen Finley, Village Voice, June 24, 1986, at 17; Karen Finley, ArTforum, Mar. 1987, at 130-31.

73. The "Kitchen" is a leading institution for performance and video art in New York. 
for a Screw Magazine party. ${ }^{74}$ When asked if anything made Sprinkle's performance at the Kitchen "art" and her performance for Screw "pornography," a spokesman for the Kitchen said, "Here it was performed in an art context." $" 75$ Another artist who defies the boundary between art and obscenity is the filmmaker Richard Kern, best known for his "Death Trip" films. ${ }^{76}$ Kern's work features "grisly sex and . . . violence";7 a spokesman for the Kitchen describes Kern's work as "extremely violent pornographic art films." 78

Finally, we may consider the work of the late Robert Mapplethorpe, whose classicized, elegant photographs often take as their subject graphically sexual portraits of men in homoeratic or sadomasochistic pasitions, ${ }^{79}$ and whose work recently became the center of a raging controversy. ${ }^{80}$ In the summer of 1989, in a startling yet prescient act of self-censorship, the Corcoran Gallery of Art cancelled-at the last minute, after all the invitations had gone out-a Mapplethorpe exhibition. Brandishing Mapplethorpe's virtuosic and frankly sexual pictures before Congress, Senator Jesse Helms seized the moment. Although they defeated Helms' more radical proposal, an outraged Congress nonetheless decided to eliminate Federal funding for any sexually explicit art that fails Miller's "serious value" test. ${ }^{81}$

These artists have so far escaped obscenity prosecutions, yet the Mapplethorpe controversy bears ominous witness to the anger and misunderstanding surrounding sexually explicit Post-Modern art. The climate is ripe for censorship. Not only Mapplethorpe has fallen prey. Police have stormed some of Finley's performances; ${ }^{82}$ worried gallery and club owners routinely cancel her engagements. ${ }^{83}$ She has been completely banned in

74. Telephone interview with Patrick Moore, Publicity Director, the Kitchen Center for the Performing Arts (Nov. 21, 1988).

75. Id. But Sprinkle told me that although she mixes elements of pornography and art in all her work, she feels there is a distinction between the two different modes; as she sees it, art provides more room than pornography for looking at her subject "from lots of different perspectives." Telephone interview with Annie Sprinkle (Feb. 26, 1990).

76. See Palmer, Film, Electronics and Some Music in Mixed Bill at Rilz, N.Y. Times, May 10, $1987, \S 1$, at 50 , col. 1 .

77. Hoberman, Film: Long Day's Journey, Village Voice, Nov. 5, 1985, at 23.

78. Telephone interview with Patrick Moore, supra note 74 (emphasis added).

79. Two of the most controversial Mapplethorpe pictures included one of a man with a whip protruding from his anus and another of a man's genitals bound in leather.

80. See Sischy, Photography: White and Black, THe New Yorker, Nov. 13, 1989, at 124. In contrast to Sischy's elegaic piece, the staunchly Modernist art critic Hilton Kramer denounced Mapplethorpe in the New York Times. See Kramer, Is Art Above the Laws of Decency?, N.Y. Times, July $2,1989, \S 2$, at 1 , col. 1 .

81. Pub. L. No. 101-121, § 304, 103 Stat. 741-42 (1989). The new law states: "recently works have been funded which are without artistic value but which are criticized as pornographic and shocking by any standards." This language implicitly refers to Mapplethorpe, whom Congress bitterly denounced throughout the debates; the law suggests that Congress believes Mapplethorpe's work would fail Miller's artistic value test. Id. $\$ 304$ (b)(2).

82. Carr, supra note 72 , at 19.

83. Harper, Finley's Attack on Taboos at Sushi Isn't For Timid, L.A. Times, Feb. 12, 1988, at A22, col. 2 (San Diego ed.). 
London. ${ }^{84}$ In a telephone conversation, Finley commented, "My work has been censored throughout the country." ${ }^{85}$ Filmmaker Richard Kern faces similar problems. In 1987, after showing the first few minutes of one of his "Death Trip" films, a New York club ejected Kern and the film from the premises. ${ }^{88}$ Annie Sprinkle's recent show, "Post Porn Modernist," has become the latest target for congressional criticism of contemporary art and arts funding. ${ }^{8 z}$

Furthermore, it is not difficult to envision artists like Finley or Kern experiencing problems under Miller ${ }^{88}$ Finley, for example, would seem to fit squarely under the Court's exposition of the first two prongs of the standard. The first part of Miller tests for "prurient interest," a term explained in Roth as "a shameful or morbid interest in nudity, sex, or excretion." prong of the test, for "patent offensiveness," may be met if the work "goes substantially beyond customary limits of candor." ent offensiveness goes to the heart of Finley's work; in fact, her very aim is to go "substantially beyond customary limits." Miller also gave specific examples of what a state obscenity statute could regulate; these, as well, seem applicable to Finley: "Patently offensive representations or descriptions of ultimate sexual acts, normal or perverted, actual or simulated," or "[p]atently offensive representations or descriptions of masturbation, excretory functions, and lewd exhibition of the genitals."

These are the standards that have saved previous artistic efforts in obscenity prosecutions. For example, the Court in Jenkins v. Georgia ${ }^{82}$ drew on the Miller examples to find that the film "Carnal Knowledge," while it did depict "ultimate sexual acts," did so without focusing on the actor's bodies, and with "no exhibition whatever of the actor's genitals, lewd or otherwise." "Thus the Court held that "as a matter of constitutional law"

84. Id

85. Telephone interview with Karen Finley (Aug. 1989).

86. Si't' Palmer, supra note 76. Another recent example of art censorship took place in Chicago, where policemen accompanied city aldermen as they entered the school of the Art Institute of Chicago and removed a painting depicting the late Mayor Washington in frilly women's lingerie. N.Y. Times, May 13, 1988, at A10, col. 1.

87. Str Carr, Nez Altack on Arts Funding: This Witch-hunt's for You, Village Voice, Feb. 20, 1990, at 55 (describing political furor over Sprinkle's performance at the Kitchen).

88. Se' 1 J. Merryman \& A. Elsen, Law, Ethics and the Visual ARTs 243 (1987) ("After reading about the activities of [certain performance artists], one is surprised that to date there have been no legal challenges to their artistic freedom.").

89. Roth v. United States, 354 U.S. 476, 487 n.20 (1957) (quoting Model Penal Code § 207.10 (2) (Tent. Draft No. 6, 1957)). The Court also defined "prurient" as having "a tendency to excite lustlul thoughts." Id.

90. In.; ser also F. Schader, supra note 18, at 102-03 (defining patent offensiveness as representation that goes well beyond what society normally tolerates).

91. Miller v. California, 413 U.S. 15, 25 (1973). These standards for prurience and patent offensiveness seem equally applicable to Richard Kern and to other artists.

92. 418 U.S. 153 (1974).

93. Id. at 161 . 
the film was not patently offensive. ${ }^{94}$ But these standards would offer no protection to Finley or Kern. Their work would find protection only under the serious value prong of the test, and that prong, as this Note has argued, offers little protection to Post-Modern art. Here is where the real danger of the Miller test emerges, for its wording does not even contemplate the possibility that this kind of art exists.

Perhaps, though, in spite of all these difficulties, the standard of "serious artistic value" is nonetheless workable: if an artist like Finley were challenged under Miller, she would certainly be able to find art critics to testify that her work is art. ${ }^{95}$ But critical acclaim would not guarantee such an artist protection under Miller as interpreted in Pope v. Illinois. ${ }^{96}$ In fact, the reasonable person standard called for in Pope appears to heighten rather than mitigate the dangers of Miller for sexually explicit Post-Modern artists.

Justice Stevens' dissent in Pope pointed out the threat this test poses for unpopular or misunderstood art. The new standard, he argued, will provide room for juries to disregard the testimony of experts such as art critics; a juror might conclude that the experts represent an unreasonable minority, and that the majority of the population, who are less likely to see the work as valuable, are more reasonable than the critics. ${ }^{97}$ This leeway for the jury to disregard expert testimony is extremely dangerous for artists like Finley, Sprinkle, Mapplethorpe, and Kern; because their work might appear shocking and remains far removed from lay notions of art, the majority of the population probably would not consider this work to be art. Only expert testimony could save these artists in an obscenity proceeding. ${ }^{98}$ Certainly Senator Danforth's recent comments on the Senate floor do not bode well for artists like Mapplethorpe. Danforth said of several Mapplethorpe pictures: "These are gross. These are terrible. . . . I do not think they are art . . . and my guess is that not a single resident of my state would like them. . . I could just see the faces of the people of Sedalia, or Cabool, or Mountain Grove . . .."99 Apparently, according to Senator Danforth there is not one reasonable person in Missouri who

94. Id. The Court did not apply Miller's serious value prong to the film; rather, it based its holding on the first two prongs of Miller. Nonetheless, the Court did describe the film's favorable reviews and critical acclaim. Id. at $158 \&$ n.5.

95. Of course, an undiscovered artist whose work represents a departure from current artistic practice might not be able to find critics to testify that his work is art. See infra text accompanying notes $124-27$.

96. 481 U.S. 497 (1987).

97. Pope, 481 U.S. at 512 \& n.5 (Stevens, J., dissenting).

98. See Wright, Defining Obscenity: The Criterion of Value, 22 New ENG. L. REv. 315 (1987) (emphasizing need for expert testimony in determining value).

99. 135 Cong. Rec. S12116 (daily ed. Sept. 28, 1989) (statement of Sen. Danforth). Despite his distaste for Mapplethorpe's work, Danforth nonetheless proceeded to vote against the Helms amendment. 
would think Mapplethorpe is even an artist, let alone that his art is of serious value. Pope is an extremely dangerous standard. ${ }^{100}$

Why should we care at all about First Amendment protection for these artists? The reader may think that if this is the state to which "art" has degenerated, or if only this sensationalism masquerading as art is at stake, then we suffer no great loss if obscenity doctrine does not protect this work. Yet the reader's resistance to understanding why this work should be called "art"-indeed, the reader's possible revulsion-is exactly the point: it illustrates the dramatic clash between lay notions of art and actual artistic practice. This portion of the Note justifies protection for the artists described above, but only based on the assumption that we as a society should extend First Amendment protection to "art" in general. (Whether or not that is a valid assumption is a question that exceeds the scope of this Note. $)^{101}$

As an art critic wrote of works like Finley's and Sprinkle's: "Understandably, to audiences habituated to the traditional boundaries of art, to audiences for whom easel painting was still the quintessential art activity, these performances were offensive and even insulting. . . But [these works] have been part of . . . art . . . legitimized by . . . critical designation again and again."102 Scholars and artists do care about these works. Although Robert Mapplethorpe is perhaps the most well-known of the artists described above (and this is certainly true now that Jesse Helms has made him a household name, the enfant terrible of the art world), all of these artists have won critical attention. For example, writers have noted Karen Finley's "disturbing power"103 and transfixing performances; many see her work as a powerfully subversive reading of female degradation in American society. ${ }^{104}$

Furthermore, Miller poses problems for more artists than the few I have described above. Any Post-Modern artist who uses sexually explicit material could be at risk under Miller, and the potential chilling effect is incalculable. As Karen Finley commented, "There are artists right now who are changing their art because they are scared."105 This phenomenon is particularly troubling because sexual imagery is crucial to many PostModern artworks. The censorship of sexual images has already threatened, for example, the growing body of political art about AIDS; ${ }^{108}$

100. A further problem arises due to the nature of some recent art criticism. A minority of critics today tend to question the art status of Post-Modern works which have highly sexualized content. See Smith, It May Be Good, But Is It Art?, N.Y. Times, Sept. 4, 1988, § 2, at 1, col. 1 (questioning whether Mapplethorpe's work is "not art"); Kramer, supra note 80 (Mapplethorpe's work is "a gruesome... violation of public decency").

101. Sep supra note 8 .

102. McEvilley, Art in the Dark, in Theories of ConTEMPORARY ART, supra note 61, at 296.

103. Carr, supra note 71 .

104. Karen Finley, supra note 72; Carr, supra note 72.

105. Telephone interview with Karen Finley (Aug. 1989).

106. The political and sexual content of the recent AIDS art show, "Witnesses: Against Our 
inevitably, sex figures as an important subject in this work. ${ }^{107}$ Other artists depend on their freedom to use sexual imagery as well. For example, pornography plays a central role in David Salle's painting. ${ }^{108}$ Just as pornography operates on a system of seduction (inviting the viewer to look at sexually provocative images) and frustration (you can look but you can't touch), ${ }^{109}$ Salle's juxtaposed images seduce the viewer into searching for a narrative, for some explanation of their linkage, yet deny the viewer any gratification; Salle has declared that no narrative exists. He promises a revelation and delivers nothing. Thus Salle uses the language of pornography to deconstruct the language of representation itself, drawing on the way pornography tantalizes and cheats the viewer in order to underscore the failure of the signifier in his own work. To rid his paintings of their sexual imagery would be to rob them of their power. ${ }^{110}$

Ultimately, this kind of art raises the question: should courts be the judges of artistic merit? As Justice Holmes wrote in 1903:

It would be a dangerous undertaking for persons trained only to the law to constitute themselves final judges of the worth of pictorial illustrations, outside of the narrowest and most obvious limits. At the one extreme some works of genius would be sure to miss appreciation. Their very novelty would make them repulsive until the public had learned the new language in which their author spoke. It may be more than doubted, for instance, whether the etchings of Goya or the paintings of Manet would have been sure of protection when seen for the first time. ${ }^{111}$

Or, as Justice Douglas noted, "[W]hat may be trash to me may be prized

Vanishing," led the Chairman of National Endowment for the Arts to revoke-and later, after public outcry, to restore-funding for the exhibition. See Atkins, Black Thursday, Village Voice, Nov. 26, 1989, at 31; see also Wojnarowicz, Postcards from america: X-Rajs from Hell, in WrTNESSES: Against Our Vanishing 6 (1989) (catalogue of exhibition at Artists Space Gallery).

107. For example, artist David Wojnarowicz's haunting "Sex Series (for Marion Scemama)" juxtaposes pictures of graphic sex with apocalyptic texts and images to create highly charged political art about AIDS. See Deitcher, Ideas and Emotions, ARTFORUM, May 1989, at 122.

108. Some art critics (particularly feminists) have attacked Salle for his explicit depiction of women in servile, sado-masochistic sexual positions. See Fernandez, Exposing a Phallocentric Discourse: Images of Women in the Art of David Salle, NEw ART ExAMINER, Nov. 1986, at 32; Heartney, David Salle: Impersonal Effects, ART AM., June 1988, at 121; see also Mishkin v. New York, 383 U.S. 502 (1966) (discussing prurient appeal of sado-masochistic materials).

109. See Koch, The Body's Shadow Realm: On the History of Pornographic Films, OctoBer, Fall 1989, at 3, 16-17 (noting inherent frustration of viewing pornographic film).

110. As with Salle's work, sex serves as an artistic metaphor in Mapplethorpe's art as well. His photographs conflate the marginalized status of the homosexual acts he depicts with the traditional marginalization of photography in the course of art history-its lesser status when compared to painting. Mapplethorpe, through his elegant composition and virtuosic form, defiantly classicizes these "debased" practices; the power of his work lies in its fusion of artistic and sexual discourses. See also McEvilley, Who Told Thee that Thou Was't Naked?, ARTForum, Feb. 1987, at 102 (sexual imagery crucial to art); Richards, Free Speech and Obscenity Law: Towards a Moral Theory of the First Amendment, 123 U. PA. L. Rev. 45 (1974) (noting importance of "obscene" in literature).

111. Bleistein v. Donaldson Lithographing Co., 188 U.S. 239, 251 (1903). 
by others." 112 Indeed, the history of art includes many examples of sexually explicit art works that society denounced as shocking and repulsive only later to deem them masterpieces. ${ }^{113}$ For example, the great Manet painting, Le Dejeuner sur l'herbe, caused a venomous uproar in 1863 when it was first shown because of its casual depiction of nudity coupled with its then-radical paint style. ${ }^{114}$ Even before the Post-Modern revolt in the arts, courts have long recognized that they are not proper arbiters of artistic worth. As Justice Douglas wrote: "We are judges, not literary experts .... We are not competent to render an independent judgment as to the worth of this or any other book . . ."116 And in Pope, Justice Scalia noted: "Just as there is no use arguing about taste, there is no use litigating about it. For the law courts to decide 'What is Beauty' is a novelty even by today's standards."116

\section{Is There Any Way for a Court to Distinguish Art From Obscentty in the Post-Modern ERa?}

Given that "serious artistic value" has become an obsolete standard in light of the art that has developed since Miller was decided in 1973, what should replace it? Is there a better standard which courts could use in order to distinguish "art" from obscenity? The answer to this question hinges on how we choose to define art. Rather than embarking on an exhaustive inquiry into the philosophical question "what is art?," this Note instead examines practical ways in which courts in obscenity cases might be able to determine if a work in dispute were art. This section considers, and ultimately rejects, three possible standards that courts might turn to for defining art.

\section{A. Is Art Defined by the Artist's Intentions?}

The idea grew up in the 1960's that anything an artist designates as art becomes art. ${ }^{17}$ This notion was exemplified in an anecdote about the painter Robert Rauschenberg. In response to a commission to do a portrait for a group gallery show, Rauschenberg sent not a painting but a

112. United States v, 12 200-ft. Reels of Super 8MM. Film, 413 U.S. 123, 137 (1973) (Douglas, J., dissenting); spe also Pope v. Illinois, 481 U.S. 497, 504-05 (1987) (Scalia, J., concurring) ("impossible to come to an objective assessment of (at least) literary or artistic value" based on "reasonable man" standard); Cohen v. California, 403 U.S. 15, 25 (1971) ("one man's vulgarity is another's lyric").

113. Sie B. Tilghman, But Is It ARt? 73 (1984).

114. See L. Nochlin, Realism 251 n.19 (1971).

115. Memoirs v. Massachusetts, 383 U.S. 413, 427 (1966) (Douglas, J., concurring).

116. Pope, 481 U.S. at 505 (Scalia, J., concurring); see also State v. Walden Book Co., 386 So. $2 d$ 342, 346 (La. 1980) ("This court is not prepared (nor qualified) to say [the disputed novel] lacks serious literary value.").

117. Smith, supra note 100. As with so much innovative art in this century, we may trace this notion to the work of Marcel Duchamp. See Nesbit, Ready-Made Originals: The Duchamp Model, OCTOBER, Summer 1986, at 53. 
telegram reading "This is a portrait . . . if I say so." played the telegram on the wall with all the other "portraits." The distinction between art and non-art in examples like this lies solely in the artist's intention.

Nonetheless, a definition of art that relied on this standard would prove unworkable for the courts for two reasons. First, if a court were to accept that "this is a portrait if I say so," then there would be nothing to prevent a hard-core pornographer from raising the defense that he intended his pornography to be art. Secondly, Post-Modern art would render a deeper inquiry into the purported artist's sincerity futile, because, as discussed earlier, ${ }^{119}$ Post-Modernism ridicules the notion of sincerity and rejects the possibility that a viewer can ever discover an artist's true intentions. Thus, because of the very nature of Post-Modern art, this deeper inquiry would fail. This standard certainly would protect more art than Miller does, but it would do so by eschewing any principled controls on the proliferation of obscenity. In fact, the standard does not even offer a way to guarantee artistic freedom because it would fail to account for a major theme of Post-Modern art: the rejection of sincerity.

\section{B. Does Art World Acceptance Define Art?}

Perhaps a definition of art could be as simple as this: if it's hanging in the Museum of Modern Art (or in any art context), it's art. ${ }^{120}$ Although this standard would obviously protect a great deal of art, it would also leave a great deal of art unprotected; video, performance art, and graffiti art, for example, do not depend on an art context for their current status as art in the eyes of the art world.

Another way to tackle the question would be to ask if the purported art work directs itself to an art audience. ${ }^{121}$ But this standard poses problems

118. Smith, Conceptual Art, in ConcePts of MODERN ART 258 (N. Stangos ed. 1974).

119. See supra note 66 and accompanying text.

120. See, e.g., McEvilley, supra note 102, at 289 ("If something (anything) is presented as art by an artist and contextualized as art within the system then it is art, and there is nothing anybody can do about it.").

121. This reasoning seems to underlie the Miller Court's specification that the ruling would affect only the "public portrayal of hard-core sexual conduct for its own sake, and for the ensuing commercial gain . . . ." Miller v. California, 413 U.S. 15, 35 (1973). Yet this qualification does little to distinguish art from obscenity; art has become a business, and mass-market commerciality and reproduction are often its subject. This phenomenon originated with Marcel Duchamp's "ready-mades" and flourished in Pop art, particularly Andy Warhol's use of commercial art techniques to reproduce images of consumer society, such as his famous silkscreens of Campbell's soup cans or Brillo boxes. (Warhol, of course, referred to his studio as the "Factory.") The theme of art as commerce recurs in the work of many contemporary artists, from Jeff Koons to Ashley Bickerton. Bickerton actually sells advertising spaces on his art to stores and manufacturers. Thus, a distinction based on commercia! appeal or mass-market production would fail in light of recent art. See Benjamin, The Work of Art in the Age of Mechanical Reproduction, in MODERN AFT AND MODERnISM, supra note 30, at 217; Ratcliff, The Marriage of Art and Money, ART AM., July 1988, at 77, 81; $c f$. Lockhart \& McClure, Censorship of Obscenity: The Developing Constitutional Standards, 45 MiNN. L. REv. 5, 77 (1960) (obscenity not inherent in work but rather function of its "appeal to . . the audience to which the material is primarily directed"); Mishkin v. New York, 383 U.S. 502 (1966) (holding work obscene 
as well. For example, Karen Finley often performs before "drunken, rowdy" crowds in nightclubs. ${ }^{122}$ Annie Sprinkle has followers in both the art and pornography worlds. ${ }^{123}$

Could courts defer to critics, scholars, and museums to decide what art is? This standard would not protect undiscovered artists, developing artists, unpopular artists, or artists who are "ahead of their time." Examples abound of artists in the current canon who were unrecognized or repudiated in their day. ${ }^{124}$ As the Court in Hannegan v. Esquire, Inc. noted, "What is good literature, . . . what is good art, varies with individuals as it does from one generation to another."125 Relying solely on critical acceptance to define art will inevitably chill the work of unpopular and unrecognized artists, the very people who may be most likely to change the course of art. ${ }^{126}$ As the Court has noted in its First Amendment decisions, it is essential to protect speech from the "prevailing climate of opinion."127 Courts could not achieve that goal if they were to rely on the prevailing climate of the art world as the sole indicator of whether or not a work were art. Although this standard would protect more artists than Miller does, it nonetheless would threaten to freeze the status quo in art, sacrificing an entire sector of artistic expression.

\section{Would a Trier of Fact Know Art When He Sees It?}

Art, like obscenity, may be difficult to define, but does that mean that a judge will not be able to recognize it? Will a court or a jury simply "know it when they see it"? ${ }^{128}$ With Post-Modern art, the answer is no. Because

because of its appeal to "deviant" sexual group).

122. Carr, supra note 72 .

123. This kind of art also defeats the distinction that Professor Schauer draws between hard-core pornography and art. See Schauer, supra note 47, at 922-23. Schauer argues that pornography acts as a sexual surrogate for the viewer, affecting him only physically, whereas art and other protected speech appeal to the "intellectual process." Yet Mapplethorpe's work, for example, challenges this distinction. For some viewers, the erotic content of Mapplethorpe photographs may constitute their main appeal. Furthermore, Schauer does not account for the long tradition of eroticism in art, in which sexual arousal is art's primary-perhaps exclusive-goal. See, e.g., United States v. 113 Prints, 128 F. Supp. 280 (D. Md. 1955) (reproductions of Greek, Roman, and Etruscan art and artifacts which depicted acts of sodomy and other sexual practices were "erotic" and obscene).

124. Sep, e.g., L. Steinberg, Contemporary Art and the Plight of its Public, in OTHer CriteRIA, supra note 27, at 3, 15; see also H. Gardner, ART Through THE Ages 690-93 (6th ed. 1975) (French salon denied access to painters Courbet and Manet).

125. 327 U.S. 146, 157 (1946).

126. Furthermore, some artists-feminists in particular-denounce the critical curatorial establishment as a biased system that refuses to acknowledge and represent the work of many women artists. For example, a group of performance artists in New York who call themselves the "Guerilla Girls" stage protests against what they view as the male-dominated network of museums and galleries. Loughery, Mrs. Holladay and the Guerilla Girls, ARTs, Oct. 1987, at 61. The Guerilla Girls offer provocative statistics. For example, in all of New York City's museums in 1987, only one oneperson show featured a woman artist. Id.; see also Nochlin, Why Have There Been No Great Woman Arlists?, ARTNEws, Jan. 1971, at 23.

127. Roth v. United States, 354 U.S. 476, 484 (1957).

128. This is, of course, a reference to Justice Stewart's famous remark on hard-core pornography, "I know it when I see it," in Jacobellis v. Ohio, 378 U.S. 184, 197 (1964) (Stewart, J., concurring). 
many contemporary artists are so estranged from lay notions of what constitutes "art," courts might refuse to recognize them as artists in spite of wide critical acceptance by the art community. This standard goes to the heart of the problem of defining Post-Modern art: its rebellion against traditional notions of the essential nature of art. The standard would protect less art than Miller and thus appears to offer no solution.

The real problem with devising a standard by which to evaluate PostModern art derives from the nature of Post-Modernism, a rebellious movement that attacks any standard used to judge it. The very proposal of any one standard would defeat the thrust of this Note: that "art" in its recent incarnation violates any definition we give it. The standards discussed above provide alternatives to Miller, yet none of them offers a satisfactory test. As long as we proscribe any pocket of sexually explicit speech, we will endanger some spectrum of artistic speech as well. Although the first two standards would protect some (and perhaps most) sexually explicit Post-Modern art, and while they both would protect more contemporary art than the Miller test does, each of these alternative standards would also leave some art unprotected. And this unprotected art might be the art we most care to protect: daring or iconoclastic works that would further challenge our notions of what art is.

\section{Conclusion}

Many have written about the failure of the Miller Court to provide a principled definition of "obscenity." The intense difficulty of this task has generated tremendous disagreement among the members of the Court; it is the very difficulty that led Justice Brennan, the chief architect of Roth, to abandon after sixteen years any attempt to define obscenity, to argue that we should no longer try to exclude obscene speech from the protection of the First Amendment. "Obscenity" is not the only term in Miller that is difficult to define. "Art," one of the very areas of speech the Miller Court attempted to protect, proves equally elusive.

"Art," by its nature, will call into question any definition that we ascribe to it. As soon as we put up a boundary, an artist will violate it, because that is what artists do. In the end, we as a society are left with a choice: either we protect art as a whole or we protect ourselves from obscenity. But we choose one at the sacrifice of the other. It is impossible to do both.*

\footnotetext{
* Author's note: After this Note went to press, obscenity indictments were issued against a Cincinnati museum and its director for displaying works by Robert Mapplethorpe.
} 